\title{
Method of Determination of Rivanol by Laser Induced Fluoroscence
}

\author{
ION PALARIE ${ }^{1}$, MARIUS CIPRIAN VARUT ${ }^{2 *}$, LARISA MARINA ELISABETH CHIRIGIU ${ }^{2}$ \\ ${ }^{1}$ University of Craiova, Faculty of Science, Department of Physics, 13 A. I. Cuza Str., 200585, Craiova, Romania \\ ${ }^{2}$ University of Medicine and Pharmacy of Craiova, Faculty of Pharmacy, 2 Petru Rares Str., 200349, Craiova, Romania
}

\begin{abstract}
In this paper has been developed a new method for determination of Ethacridine lactate (rivanol) by laser induced fluorescence (LIF). The method has been used in order to avoid the possibility of error induced in determination of aqueous solution of rivanol by spectrophotometric method due to the shift of absorption band to short wavelength with decreasing of the concentration. The new method allows the determination of rivanol at low concentrations, in the range of $1 \mu \mathrm{M}$.
\end{abstract}

Keywords: Ethacridine lactate (ethacridine monolactate monohydrate), Rivanol, laser induced fluorescence (LIF)

Ethacridine lactate (ethacridine monolactate monohydrate) has its structure presented in figure 1. Its formal name is 2-ethoxy-6,9-diaminoacridine monolactate monohydrate $\left(\mathrm{C}_{15} \mathrm{H}_{15} \mathrm{~N}_{3} \mathrm{O} \cdot \mathrm{C}_{3} \mathrm{H}_{6} \mathrm{O}_{3} \cdot \mathrm{H}_{2} \mathrm{OM}=361.4 \mathrm{u}\right)$. It forms orange-yellow crystals with a melting point of $226{ }^{\circ} \mathrm{C}$ and it has a stinging smell. The solid form it is insoluble in ether and has a low solubility in alcohol, but it is very well dissolved in water.<smiles></smiles>

Fig. 1. Ethacridine lactate

Nowadays bacterial infections are a major cause of morbidity and mortality, affecting people and animals. Ethacridine lactate has disinfecting properties, induce a change in cytokine profile by a preferential mechanism of action involving Th1-type immune reaction [1]. Among the major functions of Th1 lymphocytes during immune responses is the promotion of macrophage activation to kill and digest phagocytosed bacteria, having the capacity to enhance antibacterial defence reactions in microbial contaminated wounds. In many cases, impaired wound healing is the result of an underlying disease (autoimmunity or cancer), immunosuppression, or even stress. A topical antiseptic that would notonly avoid additional compromise of the host's defence reactions but also would positively support the immune system in its efforts to control wound infection will be of substantial clinical importance. Some recent studies indicate that plant extracts can have a synergism effect with different antibiotics and can slow dawn bacterial infection [2].

Ethacridine lactate is primary use as an antiseptic in solutions of $0.1 \%$. It is effective against mostly Grampositive bacteria, such as Streptococci and Staphylococci, but ineffective against Gram-negative bacteria such as Pseudomonas aeruginosa [3]. Ethacridine is also used as an agent for second trimester abortion. Up to $150 \mathrm{~mL}$ of a $0.1 \%$ solution is instilled extra-amniotic using a Foley catheter. After 20 to $40 \mathrm{~h}$, mini labour ensues. In China, an intra-amniotic method has also been used [4].

Usually Ethacridine lactate is well determined by HPLCUV but the obtained detection limitis at $1.1 \mathrm{ng} / \mathrm{mL}(\sim 3 \mu \mathrm{M})$, in the ppm range. By using HPLC-LIF technique the detection limit can be reduced to ppb range as it is the case for quinine [5]. Some research teams reported simultaneous detection of ethacridine and mifepristone in human plasma by HPLC-UV [6].

In this study we develop a method based on laser induced fluorescence (LIF) in order to obtain a low detection limit for Ethacridine lactate. The detection limit by LIF was found to be $1.13 \mu \mathrm{M}$ while for spectrophotometric method the limit is $29.6 \mu \mathrm{M}$.

\section{Experimental part}

First of all, we try the determination of ethacridine lactate by the spectrophotometric method. For that, we prepared aqueous solutions of rivanol of concentrations between $0.029 \mathrm{mM}$ and $1.130 \mathrm{mM}$. The samples were obtained by dilution in a quart cuvette with four transparent faces. The thickness of the cell was $1 \mathrm{~cm}$.

The absorption spectra were obtained by using $\$ 2000$ UV-Vis Ocean Optics spectrophotometer with a tungstenhalogen lamp LS-1. For laser induced fluorescence we used an $\mathrm{Ar}^{+}$laser, INNOVA 308C type, from Coherent. The wavelength used for LIF has the value $476.5 \mathrm{~nm}$, because this it is located into the absorption band of rivanol. The power of the laser beam has the values $400 \mathrm{~mW}$ and was measured with a power meter MAX-FIELD TOP II, from Coherent. The LIF and absorption spectra could be obtained for the same sample by using an orthogonal path for laser beam and tungsten-halogen light. The experimental setup can be seen in figure 2 .

\section{Results and discussions}

For the concentration $1.310 \mathrm{mM}$ the maximum of absorbance (1.784) is obtained for the wavelength 449.56 $\mathrm{nm}$. We remark that the absorbance of the prepared samples decreases as the concentration decrease. All the concentrations prepared for spectrophotometric determination were indicated in figure 3.

Also, we conclude that the wavelength corresponding to the maximum of the absorption spectra decrease if the concentration of the sample decreases. Because of this behaviour, the measurements of rivanol concentration can be profound affected. The absorbance of the samples for wavelength $449.56 \mathrm{~nm}$ is represented in the figure 4.

If we analyse the calibration curve of the rivanol we can observe that the precision of this method is good for the concentrations between $0.029 \mathrm{mM}$ and $1.130 \mathrm{mM}$. For concentration less than $0.029 \mathrm{mM}$ the calibration curve 


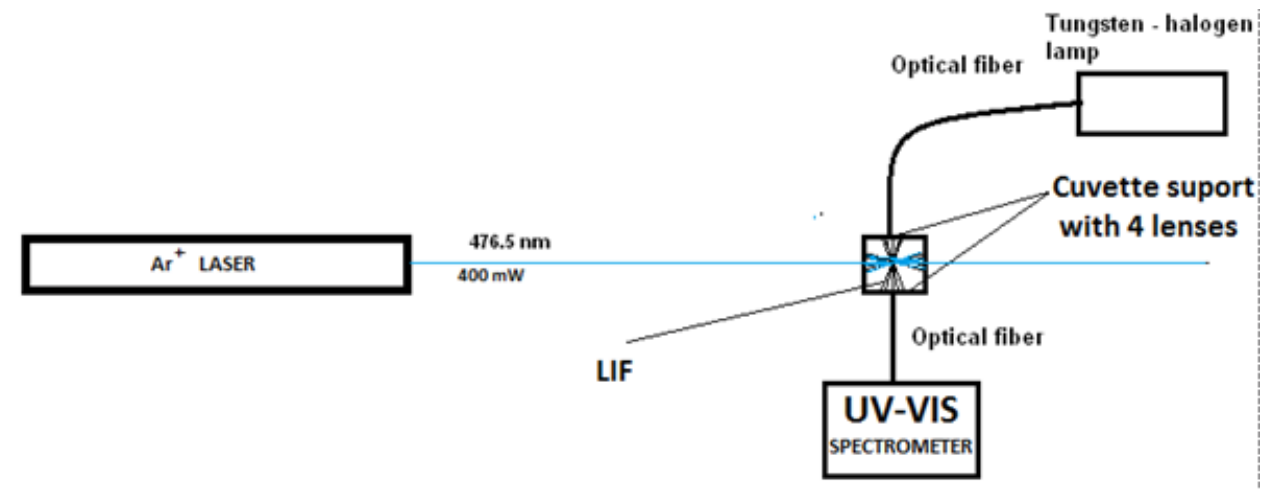

Fig.2 Experimental setup used for UV-Vis and LIF measurements

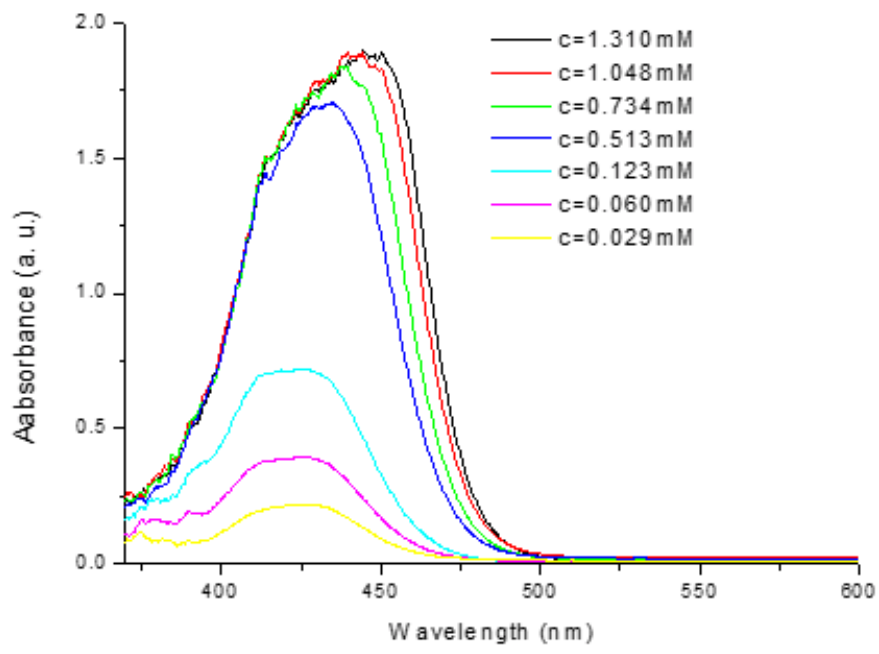

Fig. 3. Absorption spectra for solutions of rivanol at various concentrations
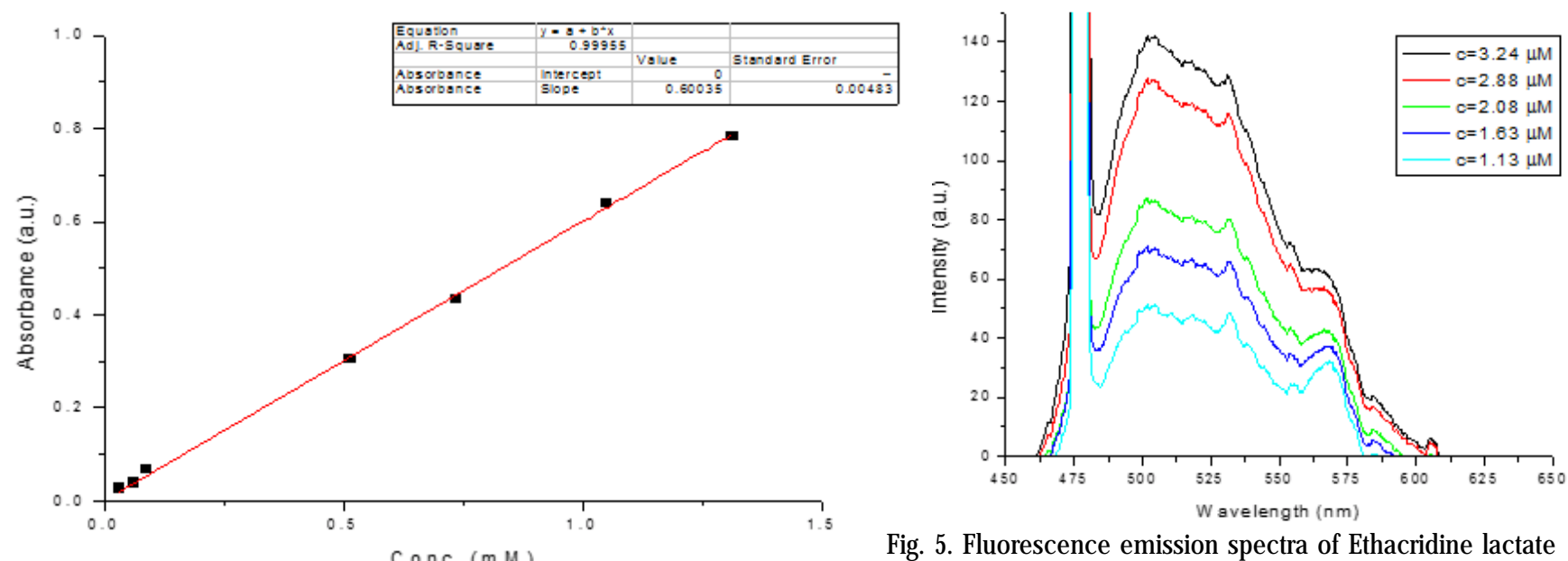

Fig. 4. Calibration curve of the Ethacridine lactate by spectrophotometry

Fig. 5. Fluorescence emission spectra of Ethacridine lactate obtained by LIF

loss its linearity due to the limitation of the sensitivity of the spectrophotometer. The fluorescence spectra for rivanol at different concentrations are presented in the figure 5 .

For all the used concentrations, the maximum of the emission band corresponds to the same wavelength, $503.86 \mathrm{~nm}$. The dependence of the emitted intensity at this wavelength for different concentrations is given in figure 6 .

From figure 6 can be observed that graph has a good linearity, the correlation coefficient being 0.99939 . Consequently, the good linearity of the calibration curve at low concentrations is making this method suitable for trace analysis of Ethacridine lactate.

At low concentrations the dimer form is absent so the wavelength shift is not observed. As a consequence, the precision of the measurement is high because of the lack of errors introduced by the wavelength shift with

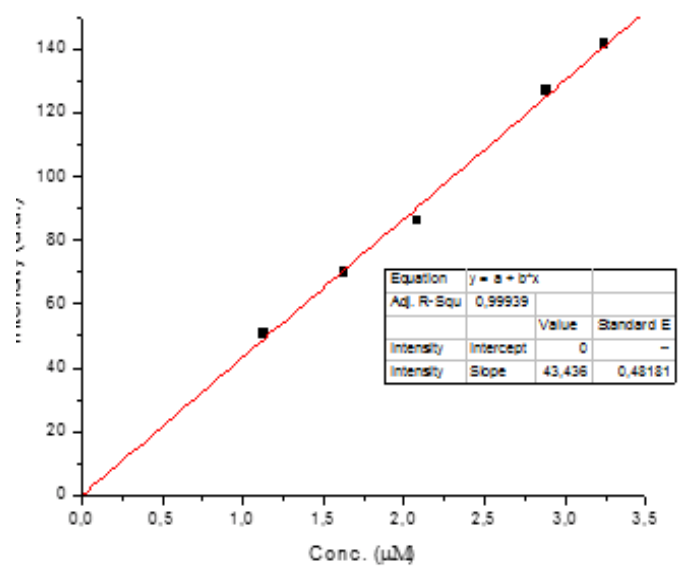

Fig. 6 Calibration curve of Ethacridine lactate by LIF concentration. 


\begin{tabular}{|c|c|c|c|c|}
\hline No. & $\begin{array}{l}\text { Prepared conc. } \\
\qquad(\mu \mathrm{M})\end{array}$ & $\begin{array}{c}\text { Emission } \\
\text { at } 503.86 \mathrm{~nm} \\
\text { (a.u.) }\end{array}$ & $\begin{array}{c}\text { Concentration } \\
\text { by LIF } \\
(\mu \mathrm{M})\end{array}$ & Statistic \\
\hline 1 & 2.0025 & 86.24 & 1.994 & \multirow{10}{*}{$\begin{array}{c}\mathrm{SD}=0.031427 \\
\bar{X}=1.997 \\
\mathrm{~S}^{2}=9.4122 \cdot 10^{-4} \\
\mathrm{~S}=0.0306 \\
\mathrm{~S} \bar{X}=9.7016 \cdot 10^{-3} \\
\mathrm{t}=0.566 \\
\mathrm{t}_{\mathrm{n}-1 \mathrm{P}}=2.26 \\
\mathrm{P}=95 \%\end{array}$} \\
\hline 2 & 2.0025 & 84.52 & 1.952 & \\
\hline 3 & 2.0025 & 87.44 & 2.014 & \\
\hline 4 & 2.0025 & 89.22 & 2.053 & \\
\hline 5 & 2.0025 & 85.40 & 1.974 & \\
\hline 6 & 2.0025 & 86.21 & 1.991 & \\
\hline 7 & 2.0025 & 88.34 & 2.034 & \\
\hline 8 & 2.0025 & 86.65 & 2.003 & \\
\hline 9 & 2.0025 & 86.20 & 1.988 & \\
\hline 10 & 2.0025 & 85.24 & 1.966 & \\
\hline
\end{tabular}

Table 1

DETERMINATION OF THE ETHACRIDINE

LACTATE FROM A STANDARD SOLUTION BY LIF

\section{Conclusions}

In the case of Ethacridine lactate the LIF method showed that the detection limit of the concentration determination was almost 30 times lower than the corresponding one from the spectrophotometric method. The proposed method is economic, simple, sensitive, reproducible and accurate and can be used for the routine analysis of ethacridine lactate.

Acknowledgments: The authors acknowledge Dr. Sarpe Cristian from Kassel University, Germany, for fruitful discussions.

\section{References}

1. C. REINHARDT, T. GESKE AND . M. SCHMOLZ, A topical wound disinfectant (ethacridine lactate) differentially affects the production of immunoregulatory cytokines in human whole-blood cultures, WOUNDS, vol. 17, no. 8, pp. 213-221, 2005.

2.VARUT, R.M., ROTARU, L.T., GC-MS, HPLC, TLC of Dorycnium herbaceum Tincture Species and Synergistic/Antagonist Effect Testing in Combination with Antibiotics, Rev. Chim. (Bucharest), 68, no. 2, 2017, p. 228-231
3. A. A. ADARCHENKO, A. P. KRASIL'NIKOV AND O. P. SOBESHCHUK, Antibiotiki i Khimioterapiia, 1aa, vol. 34, no. 12, pp. 902-907, 1989. 4. S. C. KOELZER, . H. HELD AND S. W. TOENNE, Self-induced illegal abortion with Rivanol $\cap$ : A medicolegal-toxicological case report, Forensic Science International, vol. 268, pp. e18-e22, 2016.

5. X. FEAS, C. A. FENTE AND A. CEPEDA, Fast and Sensitive New High Performance Liquid Chromatography Laser Induced Fluorescence (HPLC-LIF) Method for Quinine. Comparative Study in Soft Drinks, Journal of Liquid Chromatography \& Related Technologies, vol. 32, pp. 2600-2614, 2009.

6. Z. GUO, D. WEI, G. YIN, S. WANG AND S. ZHAO, Simultaneous determination of rivanol and mifepristone in human plasma by a HPLC-UV method with solid-phase extraction, Journal of Chromatography, vol. 456, p. 312-317, 2007.

Manuscript received: 23.06 .2018 